AperTO - Archivio Istituzionale Open Access dell'Università di Torino

\title{
Results of Mediation and Cross-Border Enforcement of Mediation Agreements
}

\section{This is a pre print version of the following article:}

Original Citation:

\section{Availability:}

This version is available http://hdl.handle.net/2318/138845

since 2016-07-05T16:26:36Z

Published version:

DOI:10.1007/s12027-013-0309-9

Terms of use:

Open Access

Anyone can freely access the full text of works made available as "Open Access". Works made available under a Creative Commons license can be used according to the terms and conditions of said license. Use of all other works requires consent of the right holder (author or publisher) if not exempted from copyright protection by the applicable law. 


\title{
Results of Mediation and Cross-Border Enforcement of Mediation Agreements ERA FORUM, 2013
}

Prof. Dr. Elena D’Alessandro University of Turin

elena.dalessandro@unito.it

\begin{abstract}
The Author identifies three different methods of enforcing a cross-border mediated agreement. The first method consists in obtaining the enforcement in the Member State where the agreement was reached. The second method consists in making the mediated agreement, which has not been yet declared enforceable in the Member State in which it was concluded, enforceable in the State where the enforcement should take place. The third and last possibility in order to enforce a Cross-border agreement within the European Judicial Area consists in using the Regulation No 805/2004 and No $44 / 2001$.
\end{abstract}

Keywords: Cross-Border Mediation, Enforcement, European Enforcement Order

\section{Introduction}

If mediation is successful, the parties reach an agreement.

Agreements reached through mediation are generally voluntarily implemented. However, in principle, it cannot be excluded that a mediated agreement may be later repudiated by one of the parties. In order to avoid such risk, the mediated agreement could be enforced.

The enforcement of agreements resulting from cross-border mediation is within the scope of the Directive 2008/52/EC (also referred to hereinafter as "the EU- Mediation Directive").

\section{Enforcement under the EU-Mediation Directive: Three Alternatives}

The Member States ${ }^{1}$ were under a duty to transpose EU Mediation Directive on certain aspects of mediation in civil and commercial matters into their national legislation before 21 May 2011.

It is well known that the EU Mediation Directive had to be applied:

A) To civil and commercial matters, including family and employment disputes ${ }^{2}$;

B) In cross-border disputes;

C) In mediation processes conducted by a third person or a judge who is not responsible for any judicial proceedings concerning the dispute in question ${ }^{3}$.

\footnotetext{
${ }^{1}$ Except Denmark. According to its Recital 30, Denmark does not take part in the adoption of the Directive 2008/52/EC and is not bound by it or subject to its application.

${ }^{2}$ See Recitals 10, 20 and 21. Conversely, Directive 2008/52/EC does not concern, in particular, revenue, customs or administrative matters or to the liability of the State for acts and omissions in the exercise of State authority (acta iure imperii).

${ }^{3}$ The scope of Directive 2008/52/EC excludes attempts made by the court or the judge of the pending proceeding to settle a dispute in the course of judicial proceedings concerning the dispute in question: see Article 3 a.
} 
In its Article 2, para. 1, the Directive defines a "cross-border dispute" as one in which at least one of the parties is domiciled or habitually resident in a Member State other than that of any other party on the date on which:

(a) The parties agree to use mediation after the dispute has arisen;

(b) Mediation is ordered by a court;

(c) An obligation to use mediation arises under national law; or

(d) An invitation to mediation is made to the parties.

As established in Article 2, para. 3, domicile shall be determined in accordance with Articles 59 and 60 of Regulation (EC) No 44/2001 (Brussels I Regulation)

Conversely, Article 2 of EU Mediation Directive does not contain any particular definition of the concept of "habitual residence". Presumably, the national courts will refer to the ECJ case law on the meaning of "habitual residence" adopted in other European rules, such as e.g. the Council Regulation (EC) No 2201/2003 (Bruxelles II) ${ }^{4}$.

One of the main aims of the EU-Mediation Directive is that mediated settlement agreements will be recognised and enforced in one Member State if made in another Member State as if they were court judgments. This is an important step in enhancing the efficacy of cross border mediation within the EU. Article 6 of the EU-Mediation Directive requires all the Member States to ensure that it is possible for the parties, or for one of them with the explicit consent of the others, to request that the content of a written agreement resulting from mediation be made enforceable. The content of such an agreement shall be made enforceable unless, in the case in question, either the content of that agreement is contrary to the law of the Member State where the request is made or the law of that Member State does not provide for its enforceability.

More specifically, in order to have the agreement resulting from mediation declared enforceable there are three alternatives.

\section{First alternative}

The first possibility, in order to have the agreement resulting from mediation declared enforceable, consists in obtaining the enforcement in the Member State in which the agreement was reached, according to the lex fori. At this regard, however, it must be taken into account that Article 6 of the EU-Mediation Directive requires the "explicit consent" of all parties in order to have the crossborder mediated agreement declared enforceable by a court or in order to have the cross-border mediated agreement made into a notarial instrument. Consequently, the majority of Member States, which have transposed the EU-Mediation Directive into their national legislation, according to Article 6, require the "explicit consent" of all parties of the mediation. This is so, for example, in England, France, Spain, Ireland, Belgium, Sweden, Cyprus, Lithuania, Finland, Bulgaria, Portugal and Romania, but not in Italy (see infra).

\footnotetext{
${ }^{4}$ See e.g. ECJ, case C-497/10 PPU, Mercredi/Chaffe [2010], available at www.curia.europa.eu.
} 
In Italy, the EU Mediation Directive was implemented on March 24, 2010, by virtue of the Legislative Decree No 28/2010 (decreto legislativo No 28/2010) ${ }^{5}$ and the subsequent Ministerial Decree of October 18, 2010, No 180.

If the cross-border mediated agreement was signed in Italy, it shall be enforced there according to the Legislative Decree No 28/2010.

The new Legislative Decree No 28/2010 does not confine itself to cross border mediation, but it also applies to domestic mediation. Particularly, it applies to mediation administered by a qualified mediation body. Indeed, the Legislative Decree No 28/2010 requires a registration in a register kept by the Italian Ministry of Justice for mediation bodies that want to conduct mediations in compliance with the Decree. Training bodies are also required to register, to submit their training programmes, and to implement a system of quality control reporting back to the Ministry of Justice. Mediation bodies, that could be public or private, act in a free market even if under the control provided by the necessary entry in a register kept by the Ministry of Justice. Mediators training is under the State control too, through the compulsory entry in a register for mediators training organizations. D. M. No 180/2010 sets the rules for mediators training.

According to Article 12 of Legislative Decree No 28/2010, signed written agreements ${ }^{6}$ shall be made enforceable by the President of the competent court (Tribunale) ${ }^{7}$ upon a party's application ${ }^{8}$ (so called "homologation" or "exequatur proceedings").

Briefly summarizing, the Legislative Decree No 28/2010 provides as follow:

A) The declaration of enforceability issued by the President of the Tribunal (exequatur) is the general remedy for enforcing mediated agreements ${ }^{9}$;

B) The declaration of enforceability shall be obtained upon application of an interested party, even without the explicit consent of the others;

C) There is no time limit on enforcing mediated agreements;

D) Exequatur proceedings are conducted inaudita altera parte;

\footnotetext{
${ }^{5}$ For a detailed overview on the Italian Legislative Decree No 28/2010 and the Italian mandatory mediation see e.g. Colvin A. (8) 739-744; Dalla Bontà S. (13).; Lupoi M. A. (22); Bandini A.-Soldati N. (1) 234 ff.; Bove M., La riforma in materia di conciliazione tra delega e decreto legislativo, Rivista di diritto processuale, 343-362 (2010); Bove M. (5); Canale G. (6) 616-630; Cuomo Ulloa F. (9); Dalfino D. (10); Tiscini R. (31); Zucconi Galli Fonseca E. (33).

${ }^{6}$ Enforcement of oral settlement agreements is not permitted by Italian law.

Written agreements must contain: $i$ ) a description of rights \& obligations of parties; $i$ ) the signatures of the parties; iii) the signature of the mediator.

Written agreements may contain: $i$ ) the applicable law on the mediated agreement: $i$ ) contract penalties.

${ }^{7}$ In case of domestic mediation, the interested party, usually the creditor, may, by motion, apply to the President of the Tribunal where the mediation body has its main office. Pursuant to Article 28 of the Italian Code of Civil Procedure, parties are not entitled to enter into an agreement by which they depart from the rules governing venue with reference to the territory.

In case of cross-border mediation, the interested party may apply to the President of the Tribunal of the judicial district in which the enforcement proceedings shall take place. There is no need that the agreement be signed in Italy, before a qualified mediation body.

${ }^{8}$ It is to be noted that the so called "exequatur procedure", mentioned in the text, is to be distinguished from a settlement resulting from a consent judgment.

${ }^{9}$ Theoretically, it would be possible to have a mediated agreement notarized by a notary, pursuant to Article 11.3 of the Legislative Decree No 28/2010. This way, as an authentic instrument, the mediated agreement shall become enforceable without the intervention of a court.
} 
E) In order to uphold the request, rectius in order to enter an order of homologation, the President of the Tribunal has to ascertain the prima facie existence of the agreement. Thus, the request for enforcement shall be refused if the agreement appears to be violating the Italian public policy or an Italian mandatory rule (so called norma imperativa) ${ }^{10}$. Due to the fact that in Article 12 there is no prescriptive indication, there is some doubt as to whether the President of the Tribunal has a duty to justify (motivate) the rejection of enforcement. Nevertheless, the reasons for such a decision are undoubtedly useful. Even if the Tribunal upholds the application, it will be possible at any time for a party to start subsequent proceedings for the annulment of the agreement (obviously when Italian law is the applicable law ${ }^{11}$ ) previously declared enforceable notwithstanding legal error (errore di diritto) (Article 1969 of the Italian Civil code ${ }^{12}$ ) regarding the subject matter of the dispute or on the grounds of lack of legal capacity. In addition, the parties, or one of them, may suit to have the enforced agreement declared void, if such agreement concerns an unlawful contract (Article 1972 of the Italian Civil Code). Under this point of view, in Italy, there are no differences between a mediated settlement and a settlement reached by the parties without the help of a mediator. In both cases agreements are to be treated according to the rules applied to "contracts".

On the other hand, however, a mediated agreement declared enforceable by the competent court shall be enforced in Italy under the same conditions as "judgments"13.

Article 12 of Legislative Decree No 28/2010 is silent regarding the possibility of an appeal, for the petitioner, against the order denying the enforcement. The positive solution seems to prevail ${ }^{14}$. Thus, in the event of a settlement declared enforceable, a difference is still maintained between judgments and mediated agreements. According to the majority of Italian scholars ${ }^{15}$, remedies (so called compulsory measures ex Article 614-bis of the Italian Code of Civil Procedure ${ }^{16}$ ) to coerce a reluctant debtor to do or not to do something which only the debtor can perform ${ }^{17}$ are available only in the case of non compliance of judicial decisions ${ }^{18}$, and not in the case of non compliance of settlements. In order to coerce a reluctant debtor to do or not to do something only a contract remedy is offered: pursuant to Article 11, para. 3 of the Legislative Decree No 28/2010 parties may

\footnotetext{
${ }^{10}$ However, the parties shall include in the settlement a clause on the lines of the following: "In the event that any part of this settlement agreement shall be found to be illegal or in violation of public policy, or for any reason unenforceable at law, such finding shall not invalidate any other part hereof". Text quoted by Partridge M. V. (27) 177.

${ }^{11}$ The parties are free to choose the law applicable to the mediated agreement. For instance they may agree that "the settlement agreement shall by governed by and construed in accordance with the law of Italy". In the absense of choice, the applicable law should be determined in accordance with Article 4 of the Regulation (EC) No 593/2008. This is so because Article 1 (e) excludes from the scope of the Regulation arbitration agremeents and agreements on the choice of court, which are contracts with procedural effects, but not mediated agreements, which are substantive contracts. For a concurring view see Orejudo Prieto de los Mozos P. (26); Jagtenberg R.-De Roo A. (19) 207 ff. believes that, except as otherwise provided by the parties, the settlement agreement is governed by the lex fori mediatoris (see Article 4, para. 3 , of the Regulation EC No. 593/2008).

12 See Beltramo M.\& S. (2) 137.

${ }^{13}$ For a general overview of Italian enforcement procedures, see Silvestri E. (29) and Lupoi M. A. (23) $90 \mathrm{ff}$.

${ }^{14}$ Compare Bove M. (5) 351; Bove M. (4) 18 ; Canale G. (6) 628; Dalfino D. (10) 68; Cuomo Ulloa F. (9) $257 \mathrm{ff}$.

${ }^{15}$ Bove M. (5) 351-352; Canale G. (6) 629; Dalfino D. (10) 67 ff.; Luiso F. P. (21) 1261.

${ }^{16}$ See Grossi S. - Pagni M. C. (16) 400 and Lupoi M. A. (23) 90 ff.

${ }^{17}$ For instance "a famous painter who is hired to paint a portrait, and refuses to fulfil his obligation": Example quoted by Silvestri E. (29) 187.

${ }^{18}$ See Caponi R. (7) $143 \mathrm{ff}$.
} 
negotiate and introduce a penalty clause into the mediated agreement. Under Italian law, such an agreement, whose main purpose is to deter the promisor from defaulting on his undertaking, is valid. In Italy, pursuant to Article 12 of the Legislative Decree No 28/2010, the declaration of enforceability of a cross-border mediated agreement shall be obtained upon application of one of the parties, without the explicit consent of the others, even if Article 6, para 1, of the EU-Mediation Directive states that "Member States shall ensure that it is possible for the parties or for one of them with the explicit consent of the others, to request that the content of a written agreement resulting from mediation be made enforceable".

Most Italian Scholars have pointed out that Article 12 of Legislative decree No 28/2010 is compatible with Article 6, para 1, of the Directive 2008/52/EC ${ }^{19}$. This is so because Article 6, para. 1, of the EU Directive, Article 6 only lays down minimum standards to encourage mediation in cross-border civil and commercial matters. The minimum standard consists in that a mediated agreement shall be made enforceable al least when both parties consent to that.

Nevertheless, Member States were free to introduce more favourable rules according to the principle of national autonomy. That is the case of Italy.

By way of introducing more favourable rules, Italy has emphasized the first part of Recital No 19 of the Directive 2008/52/EC under which "Mediation should not be regarded as a poorer alternative to judicial proceedings" and, as known, a judicial order shall be generally enforced on a party's motion, usually on a creditor's motion ${ }^{20}$.

\section{Germany, France, Spain, England}

If the cross-border mediated agreement was signed in a Member State other than Italy, for example Germany, it shall be enforced according to the German procedural law. As known, in July 2012, the German legislator implemented EU-Mediation Directive into national law and adopted the so-called 'Act to Promote Mediation and Other Methods of Out-of-court Dispute Resolution' (MediationsG). Under the German Code of Civil Procedure, there are 3 different ways to enforce a cross-border mediated agreement:

1) Should the parties decide to settle the dispute at an approved Mediation Centre (anerkannte Gütestelle) then the cross-border mediated agreement is automatically enforceable pursuant to section 794, paragraph 1, No 1 of the Code of Civil Procedure.

2) According to section 794, paragraph 1, No 5 of the German Code of Civil Procedure a mediation settlement agreement is also enforceable if it is notarised.

\footnotetext{
${ }^{19}$ See Bove M. (4) 18, note 19; Luiso F. P. (21) 1261.

${ }^{20}$ I disagree with Jagtenberg R. -De Roo A. (19) 285. Jagtenberg R. \& De Roo A. assume that "in a case in which one of the parties requested the homologation...the other party could halt the authorization to enforce, possibly invoking the Mediation Directive directly (which requires both parties to consent to homologation) or by invoking the ECJ case law, notably Krombach-Bambersky where it was held that ordre public does include the violation of fundamental rights of a party". The authors' reasoning is not convincing. It may be argued that, if there is a breach of the right to a fair trial every time that one of the parties applies for homologation, there must be an infringement of the guarantees to a fair trial even when a judgment, and not a settlement, is presented for enforcement by one of the parties before a court of a Member State according to Article 38 of the Regulation (EC) No 44/2001.
} 
3) A settlement agreement between lawyers on behalf of their (mediating) clients can also be enforced by a court or a notary (through notarization) pursuant to section $796 \mathrm{~b}$ or $796 \mathrm{c}$ of the German Code of Civil Procedure ${ }^{21}$.

If, for instance, the cross-border mediated agreement was signed in France, before a French mediator, it shall be enforced according to the Ordinance No 1540-2011 of November 10, 2011 and the subsequent Decree No. 2012-66 of January 20, 2012. More specifically, Article 1534 of the French code of civil procedure, states that written agreements reached through cross-border mediation shall be declared enforceable by the court which would have subject matter jurisdiction ratione materiae to hear the dispute. Pursuant to Article 6 of the EU-Mediation Directive, in order to have the agreement declared enforceable the explicit consent of all parties is required ${ }^{22}$.

Again, if the cross-border mediated agreement was reached in Spain, the enforcement shall be obtained in accordance with the Real Decreto - ley, dated March 5, 2012 on mediation in civil and commercial matters.

Briefly summarizing, in Spain a mediation settlement agreement shall be declared enforced by way of a judicial procedure (homologation).

In alternative, the mediation settlement agreement shall be notarized.

In both cases, the explicit consent of all the parties is required. In both cases, the enforcement shall be denied if the content of the cross-border mediated agreement is contrary to the Spanish public policy $^{23}$.

Particularly, an agreement resulting from mediation shall be judicially declared enforced by:

(i) the court or tribunal that heard the dispute in the first case, if judicial or arbitral proceedings were pending;

(ii) or the Tribunal of First Instance of the place where the agreement was signed if the parties went directly to mediation;

Finally, if the cross-border mediated agreement was signed in England, it shall be declared enforceable according to Rule 78.24, para. 1 of the Civil Procedure Rules, under which a mediated agreement shall be made enforceable by a Court upon request of the parties, or one of them with the explicit consent of the others.

Thus, where a party to the mediated settlement agreement: (a) has agreed in the mediated agreement that an enforcement order should be made in respect of that settlement; (b) is a party to the application under paragraph (1); or (c) has written to the court consenting to the application for the mediated settlement enforcement order, that party is deemed to have given explicit consent to the application for the mediation settlement enforcement order (Rule 78.24, para. 7).

\section{Second Alternative}

\footnotetext{
${ }^{21}$ See e.g Horstmeier G. (18); Meyer S.- SchmitzVornmoor A. (24).

${ }^{22}$ See e.g. Fricero N. (14); Tricoit J. P. (32).

${ }^{23}$ See e.g. Herreo Perezagua J. F. (17).
} 
The second alternative for obtaining an enforceable instrument with respect to cross border mediation consists in making the mediated agreement, which has not been yet declared enforceable in the Member State in which it was concluded, enforceable in the Member State where the enforcement should take place.

Such a possibility exists in some Member States, for instance:

A) In Italy, according to Article 12 of Legislative decree No 28/2010, under which a mediated agreement concerning a cross-border dispute shall be declared enforceable in Italy by the President of the Tribunal where the enforcement shall take place" 24 , i.e. there is no need that the agreement be signed in Italy;

B) In Spain, according to Article 27, Par. 2, of the Royal Decree Law on Mediation in Civil and Commercial Matters, which states that an agreement resulting from mediation that has not been declared enforceable by a foreign authority will only be enforceable in Spain upon its formalization in a public deed before a Spanish Notary Public at the instance of the parties or at the instance of one of them with the express consent of the others.

C) In Luxembourg, pursuant to Article 1251-23 Code of civil Procedure under which an agreement resulting from mediation that has not been declared enforceable by a foreign authority shall be declared enforceable by the President of the Tribunal upon a motion of both parties or upon a motion of one of the parties with the explicit consent of the others. A mediated agreement shall not be declared enforceable if it is contrary to public policy; if it is required to ensure the protection of the best interests of children; if mediation in such kind of matters is not permitted by the law of Luxembourg").

D) In Finland, according to Article 25 of the Finnish Mediation Act ("The provisions on confirmation of enforceability of a settlement reached in out of court mediation shall apply as appropriate also to a settlement reached in another European Union Member State in a court mediation procedure comparable to the procedure in chapter 2 of this Act").

\section{Third Alternative}

The third alternative for obtaining an enforceable instrument with respect to cross-border mediated agreements consists in making the mediated agreement enforceable in the State where the mediation proceedings had taken place in order to obtain its recognition in other European jurisdictions in accordance with Regulation (EC) No 805/2004 (European Enforcement Order for Uncontested Claims) or with Regulation (EC) No 44/2001.

7. The enforcement in other member States of Mediated agreements concerning the payment of a specific sum of money on the basis of Council Regulation (EC) No 805/2004

${ }^{24}$ Compare Bove M. (3); D’Alessandro E. (12). 
The agreement reached through domestic mediation, once declared enforceable (in the State in which it was concluded), shall be enforced in the Member State where the settlement was reached as well as in another Member State.

More precisely, a mediated agreement declared enforceable by the court of the Member State ${ }^{25}$ in which it was concluded, if concerning the payment of a specific sum of money, shall be certified as a European Enforcement order according to Article 24 of the Council Regulation (EC) No 805/2004. A settlement which has been certified as a European Enforcement Order in the Member State of origin shall be enforced in the other Member States without the need of a declaration of enforceability and without any possibility of opposing its enforceability. For this reason, parties may prefer to use the European Enforcement Order, as a method of enforcing cross-border agreements, when enforcement activities should take place in several Member States.

In particular, it seems that the enforcement of an Italian mediated agreement shall not be refused by the Member State of enforcement, for instance Germany, on the ground that Italy does not need the consent of all parties in order to declare them enforceable. The argument in favour of this interpretation is that Article 24 of the Regulation (EC) No 805/2004 only requires that the settlement was approved by a court. Conversely, the identification of the conditions under which a mediated agreement shall be approved by a court is discretionally established by each Member State $^{26}$.

If the mediated agreement involving pecuniary claims is made into a notarial instrument in the Member State of origin, it shall be certified as a European Enforcement Order pursuant to Article 25 of the Regulation (EC) No 805/2004 ${ }^{27}$, without any inquiry into the existence of a "real competence", by the foreign notary, to create authentic instruments.

Again, a mediated agreement involving the delivery of specific assets (so called movable properties or immovable properties ${ }^{28}$ ) made into a notarial instrument, shall be enforced in another Member State according to Article 57 of the Council Regulation (EC) No 44/200129. The State of destination shall refuse or revoke a declaration of enforceability only if the enforcement of such an instrument is manifestly contrary to its public policy ${ }^{30}$.

8. Cross-Border Mediated agreements involving the delivery of specific assets or the duty to do or to destroy something \& Brussels I Regulation

\footnotetext{
${ }^{25}$ Except Denmark, which does not take part in the adoption of the Regulation No 805/2004 and is not bound by it or subject to its application.

${ }^{26}$ A dissenting view is found in Jagtenberg R.- De Roo A. (19).

${ }^{27}$ For a concurring view, see Kropholler J. -Von Hein J. (20) 872; De Cesari P. (11).

According to Article 4 of the Regulation (EC) No 805/2004, an "authentic instrument" is a document which has been formally drawn up or registered as an authentic instrument, and the authenticity of which: (i) relates to the signature and the content of the instrument; and (ii) has been established by a public authority or other authority empowered for that purpose by the Member State in which it originates.

28 Silvestri E. (28).

${ }^{29}$ This is so because the Regulation (EC) No 805/2004 applies only to a claim for payment of a specific sum of money.

${ }^{30}$ For a general background concerning Article 57 of the Regulation (EC) No 44/2001 see: Carbone S. M. (30)267 ff.; O’Malley S.-Layton A. (25) 1035; Kropholler J.-Von Hein J. (20) 680 ff.
} 
More problematical, however, is the situation concerning agreements involving the delivery of specific assets or the duty to do or to destroy something, declared enforceable by the court of the Member State in which they were concluded. This is so because, on one hand, such kinds of obligations fall outside the scope of the Regulation (EC) No 805/2004 and, on the other, there is considerable debate about Article 58 and its interpretation due to the discrepancy between the English and French language version. The English version of Article 58 refers to a "settlement approved by a court". The notion seems to include mediated agreements, whereas the French, Italian, German and Spanish version refers to a "settlement reached before the court". It is for these reasons that the Communication from the Commission to the European Parliament, pursuant to the second subparagraph of Article 251 (2) of the EC Treaty concerning the common position of the Council on the adoption of a Regulation of the European Parliament and of the Council creating a European enforcement order for uncontested claims (COM/2004/0090 final), held that the subsequent Article 24 of the Regulation (EC) No 805/2004 combines "the English ("approved by a court”) and French («conclues devant le juge») language versions of Article 58 of Regulation (EC) No 44/2001 and explicitly includes out-of-court settlements that have become enforceable by virtue of a court decision referred to as "homologation" in French".

Thus, it should be remembered that the ECJ, in its case-law ${ }^{31}$ has made clear that "the need for a uniform interpretation of the provisions of Community law makes it impossible for the text of a provision to be considered in isolation, but requires, on the contrary, that it be interpreted and applied in the light of the versions existing in the other official languages" 32 . Consequently, "Where there is divergence between the various language versions of an EU legislative text, the provision in question must be interpreted by reference to the purpose and general scheme of the rules of which it forms part" ${ }^{, 33}$.

In my view, according to the case-law of the ECJ on the necessity of uniform interpretation, the scope of Article 58 of the Regulation (EC) No 44/2001 ("Brussels I Regulation") should be understood in a wider sense in order to include under its field of application both agreements reached before the court and settlements approved by the court. However, the question is still debated and we are waiting with interest for the judgments of the European Court of Justice on this specific topic ${ }^{34}$.

In any case, the law of the Member State of enforcement governs such kind of procedures ${ }^{35}$.

\footnotetext{
${ }^{31}$ See e.g. ECJ, Case C-29/69, Stauder/Ulm [1969] ECR 419, para. 3; ECJ, Case C-55/87, Moksel v. Balm [1988] ECR 3845, para. 15; ECJ, Case C-296/95, EMU Tabac [1998] ECR I-1605, para. 36; ECJ, Case C-63/06, Profisa [2007] ECR I-3239, paras. 13-14; ECJ, Case C-52/10, Eleftheri tileorasi AE «ALTER CHANNEL», paras. 23-24.

${ }^{32}$ ECJ, Case C-63/06, Profisa, ECR I-3239, para. 13.

${ }^{33}$ ECJ, Case C-52/10, Eleftheri tileorasi AE «ALTkmjER CHANNEL», para. 24.

${ }^{34}$ Similarly Gaudemet Tallon H. (15) 496.

${ }^{35}$ If the State of enforcement is Italy it would be possible, for the debtor, to act raising an objection to the enforcement proceedings according to Article 615 of the Italian Code of Civil Procedure ("opposizione all'esecuzione") in order to invoke the voidness/voidability of a mediated agreement, which was declared enforceable in the Member State of origin and subsequently recognized in Italy. However, the law recognizes one exception to this general rule. A debtor cannot invoke the voidness/voidability of a settlement in the course of the proceedings ex Article 615 of the Italian Code of Civil Procedure if the Court of the Member State of origin was already asked to decide whether the agreement was
} 
There are two textual arguments in favour of this approach.

The first textual argument consists in the recital No 30 of Directive No 2008/52/EC under which "The content of an agreement resulting from mediation which has been made enforceable in a Member State should be recognised and declared enforceable in the other Member States in accordance with applicable Community or national law. This could, for example, be on the basis of Council Regulation (EC) No 44/2001 of 22 December 2000 on jurisdiction and the recognition and enforcement of judgments in civil and commercial matters", including - it seems - Article 58.

The second textual argument is contained in the Regulation (EC) No 1215/2012 ("Bruxelles I bis Regulation" ${ }^{36}$ ). According to Article 2 (b) of the Bruxelles I bis Regulation "court settlement" means a settlement which has been approved by a court of a Member State or concluded before a court of a Member State or concluded before a court of a member State in the course of the proceedings. There is no doubt that the new definition includes agreements resulting from mediation, which are declared enforceable in a Member State (not necessarily in the Member State of origin)

Under the Brussels I \& Brussels I bis Regulation, the enforcement of a court settlement shall be refused only if such enforcement is manifestly contrary to public policy in the Member State addressed.

Indeed, it must be remembered that the European Court of Justice in its case Solo Kleinmotoren v. Boch (case C-414/92, Judgment of 2. June. 1994), stated that a court settlement cannot be treated as a judgment given in a dispute between the same parties in the State in which recognition is sought for the purpose of Article 27 (3) of the Convention (today: article. 34, n. 3 of the Brussels I Regulation).

In particular, the EJC ruled that "Article 27 (3) of the Convention is to be interpreted as meaning that an enforceable settlement reached before a court of the State in which recognition is sought in order to settle legal proceedings which are in progress does not constitute a "judgment" within the meaning of that provision". Article 27 (3) does not constitute a ground for non recognition”.

\section{Endnotes:}

(1) Bandini A.- Soldati N.(ed.), La nuova disciplina della mediazione delle controversie civili e commerciali, Milano, Giuffré, 2010

(2) Beltramo M.\& S., The Italian Civil Code and Complementary Legislation, Dobbs Ferry, New York, Oceana Publications, 2001

(3) Bove M., Circolazione europea della conciliazione-titolo esecutivo, Le società, 703-708 (2012);

(4) Bove M. (ed.), La mediazione per la composizione delle controversie civili e commerciali, Padova, Cedam, 2011

\footnotetext{
binding on the parties. The reason for this is that the "defence" is barred by res judicata. "Pending the opposizione, the Court may also stay the enforcement proceeding..when serious reasons are shown": Lupoi M. A (23) 99.

${ }^{36}$ Regulation (EU) No 1215/2012 of the European Parliament and of the Council of 12 December 2012 on jurisdiction and the recognition and enforcement of judgments in civil and commercial matters (recast), Official Journal of the European Union 20.12.2012 L. 351/1. The Regulation No 1215/2012 shall apply from 10 January 2015.
} 
(5) Bove M., La riforma in materia di conciliazione tra delega e decreto legislativo, Rivista di diritto processuale, 343-362 (2010)

(6) Canale G., Il decreto legislativo in materia di mediazione, Rivista di diritto processuale, 616630 (2010)

(7) Caponi R., Italian civil justice reform 2009, ZZP-Int 14, 143- 58 (2009)

(8) Colvin A., The new mediation in Italy, Arbitration, 739-744 (2010)

(9) Cuomo Ulloa F., La mediazione nel processo civile riformato, Bologna, Zanichelli, 2011

(10) Dalfino D., Dalla conciliazione societaria alla mediazione finalizzata alla conciliazione delle controversie civili e commerciali, Rassegna forense, 49-68 (2010)

(11) De Cesari P., Atti pubblici e transazioni certificabili quali titoli esecutivi europei, Foro italiano, 229-233 (2006)

(12) D'Alessandro E., Il conferimento dell'esecutività al verbale di conciliazione stragiudiziale e la sua circolazione all'interno dello spazio giudiziario europeo, Rivista trimestrale di diritto e procedura civile, 1157-1178 (2011)

(13) Dalla Bontà S., Directive 2008/52/EC: Italy's Peculiar Implementation and its Consequences on Cross-Border Civil and Commercial Disputes, XIV IAPL Word Congress on Procedural Justice, Open Afternoon, Heidelberg, July 28, 2011

(14) Fricero N., Panorama. Proc.Civ., Recueil Dalloz, No 4, 244-253 (2012)

(15) Gaudemet Tallon H., Compétence et exécution des jugements en Europe, Paris, LGDJ, 2010

(16) Grossi S. - Pagni M. C., Commentary on the Italian Code of Civil Procedure, New York, Oxford University Press, 2010

(17) Herreo Perezagua J. F., Escritura y acuerdo del mediacion: el titulo ejecutivo. BIB 2012/1141, Revista Aranzadi Doctrinal, www.westlaw.es, No 4 (2012).

(18) Horstmeier G., Das neue Mediationsgesetz, München, Beck, 2013

(19) Jagtenberg R.- De Roo A., Enforcing Mediated Settlements in Europe, in Van Rhee C.H. \& Uzelac A. (ed.), Enforcement and Enforceability, Antwerp/Oxford, Intersentia, 2010

(20) Kropholler J. -Von Hein J., Europäisches Zivilprozessrecht, 9 Auflage, Frankfurt am Main, Recht und Wirtschaft, 2011

(21) Luiso F. P., La delega in materia di mediazione e conciliazione, Rivista di diritto processuale, 1257-1265 (2009)

(22) Lupoi M. A., Recent Developments in Italian Civil Procedural Law, available at www.judicium.it (last visited April 20, 2013)

(23) Lupoi M. A., Civil Enforcement in Italy: A Comparative Perspective, in Stürner R. \& Kavano M., Comparative Studies on Enforcement and provisional Measures, Tübingen, Mohr Siebeck, 2011 (24) Meyer S.- SchmitzVornmoor A., Das neue Mediationsgesetz in der notariellen Praxis, DNotZ, 895-917 (2012)

(25) O'Malley S.-Layton A., European Civil Practice, 2 nd ed., London, Sweet \& Maxwell, 2004 (26) Orejudo Prieto de los Mozos P., The Law Applicable to International Mediation Contracts, available at www.ssrn.com (last visited August 29, 2011) 
(27) Partridge M. V., Alternative Dispute Resolution, Oxford, Oxford University Press, 2009, 177. Risse J., Das Mediationsgesetz - eine Kommentierung, SchiedsVZ, 244-254 (2012)

(28) Silvestri E., The devil is in the Details: Remarks on Italian Enforcement Procedures, in Van Rhee C. H. \& Uzelac A. (ed.), Enforcement and Enforceability, Antwerp/Oxford, Intersentia, 2010

(29) Silvestri E., Enforcement of Civil Judgments and Orders in Italy: An Overview, Bond Law Review, 183-192 (2000)

(30) Carbone S. M., Lo spazio giudiziario europeo in materia civile e commerciale, Torino, Giappichelli, 2009

(31) Tiscini R., Vantaggi e svantaggi della nuova mediazione finalizzata alla conciliazione: accordo e sentenza a confronto, Giustizia civile, 489-501 (2011)

(32) Tricoit J. P., Chronique de droit des modes amiables de règlement des conflicts, Revue de l'arbitrage, 157-199 (2012)

(33) Zucconi Galli Fonseca E., La nuova mediazione nella prospettiva europea: note a prima lettura, Rivista trimestrale di diritto e procedura civile, 653-673 (2010)

\section{Contact Details:}

elena.dalessandro@gmail.com

elena.dalessandro@unito.it 